Agro-Science Journal of Tropical Agriculture, Food, Environment and Extension Volume 14 Number 2 May 2015 pp. $30-35$

ISSN III9-7455

\title{
SOIL AND CROP MANAGEMENT PRACTICES AMONG FARMERS IN KABBA/BUNU LOCAL GOVERNMENT AREA, KOGI STATE
}

\author{
Babalola, T.S., Afolabi, S.K., Kadiri, W.O.J., ${ }^{1}$ Ayodele, O.J and ${ }^{1}$ Aruleba, J.A \\ Kabba College of Agriculture, Division of Agricultural Colleges, Ahmadu Bello University PMB 205, \\ Kabba, Kogi State \\ ${ }^{1}$ Crop, Soil and Environmental Department, Ekiti State University, Ado-Ekiti \\ pauloxti@yahoo.com,
}

\begin{abstract}
The study examined management practices among farmers in Kabba/Bunu Local Government Area of Kogi State. A two stage sampling technique was used in selecting the sample size. Structured questionnaires were used in collecting primary data from one hundred (100) sampled farmers in ten villages (Ohakiti, Odo-Ape, OlleBunu, Egbeda, Aiyetoro, Aiyede, Otu, Oke-Dayo, Okebukun and Agbadu) within the study area. Data Collected from the questionnaire were analyzed using percentage. The result from the study revealed that majority of the farmers are above the productivity age (53.8\%) of 51 years. The main crops grown in the study area is yam and cassava. 45\% of the respondents practice mixed cropping. Practices among farmers in the study area include; use of improved, varieties chemical weeding, planting of cover crop, use of inorganic fertilizer, live mulch and chemical method for control of pests. It is concluded that there is need for farmers to improve on the current practice in other to ensure optimal and profitable production.
\end{abstract}

Keywords: Soil, Crops, Management, farmers

\section{INTRODUCTION}

Understanding the relationships between crops and ecosystems is becoming an increasingly important research and development priority to establish sustainable crop management practices - in particular, the move from managing soils using chemical inputs to the use of biologically-based improved strategies is a rapidly emerging challenge. Crop and soil management involves tillage, cropping practices, crop husbandry practices and other treatments applied to the crop and soil for production of crops (Ayodele and Akande, 2009). Soil management entails the nutrient and water management; the management of physical properties such that the soil is used for optimum crop production on a sustainable basis without any adverse effect on the environment. While Crop management involves; thinning, pruning, weed control, pest and disease control, staking and other practices that create conducive environment for crop growth and development. Soils in Nigeria are the products of intensive weathering and leaching of parent materials low in weatherable minerals such that low activity clays, low organic matter content and poor nutrient fertility put a ceiling on crop yields (Anon, 2006). The consequences of its wanton uses are irreversible loss of soil potential and environmental degradation (Lal, 1986). Thus, the need for soil resources management should be a national priority.

Lal (2000) observed that crop and soil management challenges for developing countries include achieving food security with minimal risks to environment. Traditional farmers have evolved and adopted technologies to improve their production, this include mixed cropping, shifting cultivation and utilizing fallow of varying lengths in-between short cropping periods as the standard soil management and nutrient fertility restoration practice and optimizing land use by planting different crops on the same land (Okigbo, 1978; Leihner, 1983; Tongglum, et al., 2000) The in-built ecological stability and efficiency of farmers' management technologies like fallow are threatened by shortened fallows such that increased frequency of land use causes fertility exhaustion and losses of productivity. Also, the temptation to adopt large-scale commercial farms based on high-input technologies and continuous land use has resulted in 
poor results of crop and soil management practices (Ayodele and Akande, 2009).

Majority of farmers in the tropics in which the study area belong to are small scale farmers involved in subsistence farming (Agboola and Shittu, 2002) most operations under this system are carried out manually with the use of implements such as hoes and cutlasses and sometimes animal traction. Local crop varieties are used. Production under this system cannot meet the food sufficiency goal (Aruleba and Oluwatayo, 2002). The attainment of increased crop production is essentially dependent on the successful application of the basic principles that govern the various crop and soil management practices. The need for a sound appreciation of the basic principles of crop production becomes particularly important as modern crop husbandry is based on scientific experimentation and scientifically developed procedures as well as the challenge of increasing demands for food and fiber by expanding human and livestock population. Junge et al. (2009) attest to the fact that technologies exist for sustainable soil management in Nigeria but they are limited in application because they were not tested beyond research stations. An understanding of management systems among farmers will aid in the application of existing crop and soil management technologies. Therefore the need for this study arose.

\section{Objectives of the Study}

(i) Identify socio-economic characteristics of farmers in the study area.

(ii) Identify Soil and Crop management practices among famers in the study area.

\section{MATERIALS AND METHOD}

Description of the study area: The study was conducted at Kabba/Bunu Local Government Area in Kogi State. The study area is located within the Southern Guinea Savanna zone of Nigeria. It is lies within $7^{\circ} 50^{\prime} \mathrm{N}$ and $6^{\circ} 03^{\prime} \mathrm{E}$. It is an agrarian community with humid tropical climate. Rainfall spans from April to November with the peak in July to September. It has high temperature and high humidity. The dry season extends from December to March. The mean annual rainfall is 59\%. The main vegetation of the area are tall grasses, shrubs, wild oil palm, while some parts of the area however been put to cultivation of arable crops like maize, vegetables (Okro, pepper), sorghum and tubers such as yam and cassava.

Sampling procedure: A two stage sampling techniques was used for the study. The first stage involves a purposive selection of 10 villages out of the 20 villages in the LGA these was based on the level of crop production activities in the areas. The second stage involved a random selection of ten (10) farmers each from the selected villages bringing the sample size to one hundred (100) farmers.

\section{Data Collection}

Observation Techniques:- The selected villages (Ohakiti, Odo-Ape, Olle-Bunu, Egbeda, Aiyetoro, Aiyede, Otu, Oke-Dayo, Okebukun-Bunu and Agbadu ) were visited for observation on the crop and soil management practices among farmers. Questionnaires: Data were collected with the aid of a well structured questionnaire which was used to elicit information on socioeconomic characteristics, crop and soil management practices among famers in the areas. One hundred and ten (110) questionnaires were administered randomly to the farmers within ten (10) villages selected for the study.

Data Analysis: The responses were collated, added together as frequency for each response category and converted into percentages.

\section{RESULTS AND DISCUSSION}

Results on socioeconomic characteristics of the respondents are presented in table 1. 53.9\% of respondents are above 51 years of age. This revealed that old people engage in farming activities than young men in the study area. The result agrees with the reported age population of farmers in Nigeria (Olayide, 1982; Manyong et al., 2005, Ayodele and Akande, 2009). Also, result on marital status of respondents showed that $65.3 \%$ of the respondents are married. This implies that married people engage in farming activities than singles. On family size, most of the respondent have family size that is more than $5 ; 46.3 \%$ have family size of $5-7,37.6 \%$ have $8-10$ while $15.8 \%$ family size that is above 10 . This could be a source of farm labour and create the need to produce more food to meet the food demand of the family. On educational qualification of the respondents results revealed that $36.8 \%$ had primary education and $27.4 \%$ had no formal education. This may affect the perception and acceptance of improved technologies on soil management and crop improvement for increase crop production; acceptance may be hampered among the farmers. On respondents' occupation, results revealed that majority of the respondents are into farming solely (68.4\%) while those that are involve in farming and other ventures are $31.6 \%$. This implies that farming is the major occupation among the people in the study area. 


\section{Socio-Economic Characteristics}

Table 1: Socioeconomic Characteristics of the Respondents

\begin{tabular}{lll}
\hline Characteristics & No of respondents & Percentage $(\%)$ \\
\hline Age (years) & 6 & 6.3 \\
$21-30$ & 20 & 21.1 \\
$31-40$ & 18 & 18.9 \\
$41-50$ & 51 & 53.9 \\
51 above & & \\
Marital Status & 10 & 10.5 \\
Single & 62 & 65.3 \\
Married & 8 & 8.4 \\
Widow & 15 & 15.8 \\
Widower & & \\
Family Size & 6 & 6.3 \\
$2-4$ & 44 & 46.3 \\
$5-7$ & 30 & 37.6 \\
$8-10$ & 15 & 15.8 \\
10 above & & \\
Education & 26 & 27.4 \\
Non-formal Education & 35 & 36.8 \\
Primary school & 4 & 4.2 \\
Secondary Education & 30 & 31.6 \\
Tertiary Education & & \\
Occupation & 65 & 68.4 \\
Farming & 30 & 31.6 \\
Farming and others & & \\
\hline
\end{tabular}

Land Development Activities

Table 2: Land Development Activities of the Respondents

\begin{tabular}{lll}
\hline Land Development Activities & No of Respondents & Percentage (\%) \\
\hline Farming Activities & 12 & 12.6 \\
Animal Based & 73 & 76.8 \\
Crop Based & 5 & 5.3 \\
Both a \& b & 5 & 5.3 \\
Others & & \\
Land Acquisition & 10 & 10.5 \\
Lease & 20 & 21.1 \\
Purchased & 40 & 42.1 \\
Inheritance & 25 & 26.3 \\
Rent & & \\
Land Preparation & 25 & 57.9 \\
Traditional & 25 & 26.3 \\
Machine Tillage (Ploughing, harrowing & & \\
and Ridging & 5 & 5.3 \\
Zero tillage (Herbicide) & 10 & 10.5 \\
Others & & \\
Scale of Production & 53 & 55.8 \\
Commercial & 42 & 44.2 \\
Subsistence & & 45.3 \\
Cultivated Crops & 43 & 26.3 \\
Root and tubers & 25 & 10.5 \\
Cereals & 10 & 17.9 \\
Legumes & 17 & \\
Vegetables & &
\end{tabular}


Results on land development activities are presented in Table $2 ; 76.8 \%$ are into crop based farming, it showed that crop based agriculture is the major agricultural activity in the study area. On land acquisition, $42.1 \%$ of the respondents inherited their land, $21.1 \%$ of the respondents purchased their land, $10.5 \%$ leased and $26.3 \%$ rent their land. This implies that most farmers in the study area owned their land; hence they can practice long term soil management measures on their land. On Land preparation methods among the respondents revealed, $57.9 \%$ of the respondents are involved in traditional slashing and burning. The farmers prefer this method because it is cheap although the practice encourages soil nutrient depletion such as nitrogen (Babalola et al., 2013); it destroys the soil micro fauna and depletes the organic matter. Results on the scale of production revealed that majority of the respondents are into commercial production. Those that are into commercial production constitute $55.8 \%$ of the respondents while those that are into subsistence production are $44.2 \%$. Hence there is need for improved management practices for a profitable crop production. Results also revealed that $45.3 \%$ of the respondents cultivates roots and tubers, $26.3 \%$ cultivates cereals. Root and tubers crops removed more nutrients from the soil than other crops because they store food in their roots.

\section{Soil and Crop Management Practices}

Table 3: Soil and Crop Management Practices of the Respondents

\begin{tabular}{lll}
\hline Soil and Crop Management Practices & No of Respondents & Percentage (\%) \\
\hline Seed used for planting operation & 50 & 52.6 \\
Improved seed & 45 & 47.4 \\
Local seed & & \\
Control of weed & 39 & 41.1 \\
Manual weeding (hand picking and hoeing) & 51 & 53.7 \\
Chemical weeding (Herbicide) & 9 & 9.1 \\
Biological weeding & 5 & 5.3 \\
Integrated weeding management & & \\
Acidity Control & 50 & 10.1 \\
Liming & 25 & 6.3 \\
Tolerant crop & 20 & 83.6 \\
None & & \\
Control of Erosion in Farmland & 5 & 5.3 \\
Planting of trees & 20 & 21.1 \\
Relay and intercropping & 20 & 21.1 \\
Inter-racing and contour binding & 40 & 42.1 \\
Planting of cover crop & 10 & 10.5 \\
None & & \\
Soil Amendments Use & 40 & $47.4 \%$ \\
Use of organic manures & 45 & $52.6 \%$ \\
Use of inorganic fertilizer & & \\
Mulching Practice & 48 & 50.5 \\
Live mulch & 10 & 10.5 \\
Plastic mulch & 32 & 33.7 \\
In-situ mulch & 5 & 5.3 \\
Others & & \\
Soil fertility & 42 & 44.2 \\
Yes & 53 & 55.8 \\
No Pests and Diseases control & 60 & 63.2 \\
Chemical method (insecticide) & None & None \\
Biological method & 6.5 \\
Disease resistance varieties & & 6.3 \\
Integrated pest management & & 21 \\
None & &
\end{tabular}


Results on soil and crop management practices among the respondents are presented in Table $3 ; 52.6 \%$ of the respondents use improved seed varieties while $47.4 \%$ use local seed. The use of improved seed variety will encourage good output however improved management practices will be needed to achieve this. On weed 1. control methods among the respondents, $53.7 \%$ of the respondents practice chemical weeding and $41.1 \%$ practice manual weeding. This implies that farmers in 2 . the study area basically use chemical to control weed in their farming activities. On control of acidity, $10.1 \%$ of 3 . the respondents control acidity on their farms by 4 . liming, $6.3 \%$ plant tolerant crops and $83.6 \%$ do not 5 . take any measure to control acidity. Farmers in the area are not aware of the $\mathrm{pH}$ status of their soils because 6 . they do not carry out soil testing. Soil acidity is a major problem of soil productivity in the tropics and there is 7 . need for soil testing before fertilizer recommendation (Ayodele, O.J- Personal Communication). Results on erosion control showed that $42.1 \%$ of the respondents' plant cover crops to control erosion, $21.1 \%$ practice relay and inter cropping, $21.1 \%$, inter-racing and contour binding and $5.3 \%$ plant trees to control erosion on their farms. The result shows that farmers in the study area are taking measures to control erosion. Result on type of soil amendment used revealed that $52.6 \%$ use inorganic fertilizer while $47.4 \%$ use organic manure. Organic manure are bulky and slow in nutrient, this could be the reason why more farmers use inorganic fertilizer. However, organic fertilizer improves soil bulk density, structure, cation exchange capacity, the use of organic manure is important for sustainable land use management. Result on the use of mulch showed that majority of the respondents; $50.3 \%$ farmers use live mulch and $33.7 \%$ use in-situ mulch while fewer farmers use other mulch materials. The type of mulching materials used on the soil determines its impact on soil physical and chemical properties and crop yield. Mulching improves biotic activity and adds nutrients to soil thereby improving soil fertility (Babalola, et al., 2013). Also 55.8\% of the respondents are not aware of the use of legumes for soil fertility maintenance while $44.2 \%$ are aware. The addition of food grain legumes to the crops grown encourages increased soil nitrogen and improvement in the dietary plant protein uptake of the inhabitants in the study area (Olajide, 1982). Results on pest control revealed that $63.2 \%$ of the respondents adopt chemical method to control pest and diseases while $21 \%$ do not use. This implies that the most farmers in the study area applied chemical to control pests and diseases.

\section{CONCLUSION}

There is need for improvement on the current management practices among farmers in the study area in other to attain increase in arable crop production. This can be achieved through

Creation of awareness on the introduction of legumes into crop grown by farmers by relevant agricultural agencies.

Provision of soil testing facility by relevant agricultural agencies.

Creation of awareness on the use of lime

Creation of awareness on the use of organic manure.

Organization of adult education among farmers in the area.

Encourage farmers to adopt Integrated pest management in the control of pests

Efforts should be made by government and nongovernmental agencies in improving access to farm inputs for farmers.

\section{REFERENCES}

Ayodele O .J. and Akande A. O. (2009) Tenant Farmers on Ado-Iworoko road, EkitiState;Soil Management practices and imperatives for sustainable land use. (unpublished).

Agboola, A.A and Shittu, O.S (2002) Farming Systems in Nigeria. In. Agboola A.A (ed) Essentials of Agricultural Production in Nigeria, $1^{\text {st }}$ edition. Green Line Publishers, Ado-Ekiti 240p.

Anon, 2006. Nigeria Fertilizer Strategy Report. Africa Fertilizer Summit, International Conference Centre, Abuja, 9-16 ${ }^{\text {th }}$ June, 2006. 47pp.

Aruleba J. O. and Oluwatayo I. B. (2002) Agricultural Production in Nigeria Past and Present. In Agboola A.A (ed) Essentials of Agricultural Production in Nigeria, $1^{\text {st }}$ edition. Green Line Publishers, Ado-Ekiti 240p.

Babalola T. S., Ogundare, S. K., Oloniruha, J. A., Ayodele, O. J. and Ayodele, F. G. (2013) Effect of Mulch Materials on Soil Physical Properties, Yield and Yield Components of Tomato (Lycorpersicon Lycopersicum L.) in Kabba, Kogi State, Nigeria. In:Proceedings of $37^{\text {th }}$ Annual conference of Soil Science Society of Nigeria, March $11-15,2013$. Pp226-232

Junge B., Deji O., Abaidoo R., Chikoye D. and Stahr K. (2009) Farmers' adoption of soil conservation technologies: A case study of Osun State, Nigeria. J. Agric. Educ. Ext. 15(3): 257-274.

Lal, R. (1986) Land Clearing and Development in the Tropics. Balkema, Rotterdam, The Netherlands. 
Lal, R. (2000). Land use and cropping system effects on restoring soil carbon pool of degraded Alfisols in Western Nigeria. In: Lal, R., Kimble, J.M. and Stewart, B.A. (eds) Global Climate Change and Tropical Ecosystems. Advances in Soil Science. CRC Press, LLC: 157-165.

Leihner, D. (1983). Management and Evaluation of Intercropping systems with Cassava.Centro International de Agricultura Tropica, Cali Columbia. $70 \mathrm{p}$.

Manyong V. M., Ikipi A., Olayemi J. K., Omonoma B. T., Okoruwa V and Idacahaba F. S. (2005) Agriculture in Nigeria: Identifying opportunitiesfor increasing commercialization and investment IITA, Ibadan, Nigeria. 159p.
Olayide S. O. (1982) Food and Nutrition crisis in Nigeria. Ibadan University Press, Ibadan.

Okigbo, B. N. (1978). Cropping System and related research in Africa. Addis Ababa, Ethiopia. AAASA

Tongglum, A. P. Suriyapan, P., Howeler, R.H. (2000). Cassava agronomy research and adaptation of improved practices in Thailand. Major Achievements during the past 25 years. 6th Regional Cassava Workshop held in Hochiminh City. Feb. 21-25, 2000.D 